\title{
An analysis of user satisfaction on transit stop and station services on the Dar es Salaam-Arusha National Highway Road, Tanzania
}

\author{
S. S. Lushakuzi ${ }^{1} \&$ D. G. Daudi ${ }^{2}$ \\ ${ }^{I}$ Department of Logistics and Transport Studies, \\ National Institute of Transport, Dar es Salaam, Tanzania \\ ${ }^{2}$ Department of Computing and Communication Technology, \\ National Institute of Transport, Dar es Salaam, Tanzania
}

\begin{abstract}
This research focuses on transit travellers who were thought to be forgotten in the sense that there exists a low standard of transit stop and station services for them. Transit travellers expend a great deal of time and energy on out-of-vehicle walking and waiting, which significantly affects their perceived burdens of travel. The main objective of this research therefore, was to make an analysis of users' satisfaction of transit stop and station services in Dar es Salaam to the Arusha National Highway Road, Tanzania. This study is based on the valuepercept disparity theory, which was developed in response to the problem that customers could be satisfied by aspects for which expectations may never exist. The value-percept theory views satisfaction as an emotional response triggered by a cognitive-evaluative process. A survey design was adopted, with a sample of fifty (50) respondents only. Multiple methods were used to gather information. Primary and secondary data was collected, tested and found to be fit, reliable and valid for making meaningful interpretation. The research findings were based on Total Score Value (TSV) results at the transit stops and stations, which indicate unfavourable opinions and the association of all attributes were at 0.05 and 0.01 significant levels.
\end{abstract}

Keywords: users' satisfaction, transit stops, stations services. 


\section{Introduction}

Despite government efforts of making policies aimed at addressing the challenges of transport services in urban and rural areas in terms of customer satisfaction, the quality of service at the transit stops and stations is still poor (Lushakuzi [1]). The delivery of quality service in the service industry has remained one of the challenges facing organisations in meeting users' satisfaction. In order to remain competitive, service oriented firms have made quality as a focal point through the initiatives launched in past decades.

According to the reported incidences, service facilities at transit stops and stations seem either unreliable or non-existent and most of them are uncoordinated (Lushakuzi [1]). Yet, these transit stops and stations contribute to economic growth and facilitate transit, intra- and inter-urban trade, linking Dar es Salaam and the Arusha regions. Dar es Salaam to Arusha National highway road provides an important link for market centres between Dar es Salaam, the coast and Kilimanjaro and Arusha regions. Thus, the road facilitates the movement of goods and people, hence boosting production and the marketing of products. The same road can hardly cope with a rapid increase in traffic volumes due to insufficient road capacities causing very high road traffic density especially in the Central Business District (CBD) areas URT [2].

This observation shows that the objective of the government for ensuring that passengers receive satisfying services has not been met. According to Lushakuzi [1], the observable physical condition and the quality of service offered by the transit stops and stations in the Dar es Salaam to Arusha National Highway Road are not satisfactory.

For the case of transit stops and stations users, many have different experiences that have lead them to make different comments about the quality of service. Some commented on accessibility, the physical condition of transit stops and the stations' facility services and others expressed a dissatisfaction with the level of services as far as reliability was concerned.

\subsection{Research problem}

Travel by public transit involves much more than moving about on buses. A typical door-to-door trip entails walking from one's origin to a bus stop, waiting for the bus to arrive, boarding the bus, travelling in the bus, alighting from the bus and then walking to one's final destination. For that sense therefore, an efficient transport system is necessary to promote socio-economic development in the country.

Currently, there is a wide increase of complaints from transit stop and station service users, regarding the unsatisfactory services that are provided. This is due to a frequent and wide-ranging decrease of reliability, coordination and consistency of these services. These services are quite forgotten in the sense that a formally provided service no longer exists. Transit travellers are not quite sure of the intentions of services; on the other hand, they are not satisfied with 
services that are offered to them. They suffer from being improperly served and from unnecessary delays and lack of security when travelling from one's origin to one's final destination. For that matter, they expend a great deal of time and energy on out-of-vehicle walking and waiting, which significantly affects their perceived burdens of travel.

Since there is limited research on the working conditions of transit stop and station services on the national highway roads, the source of transit travellers' satisfaction has not been explored in detail.

Therefore, this study is aimed at analysing the users' satisfaction of transit stop and station services in Dar es Salaam to the Arusha National Highway Road. The main purpose of the study is to determine the extent of users' satisfaction and the challenges encountered by the government and other relevant authorities in the regulating and monitoring of provided services at these transit stops and stations.

\section{Materials}

\subsection{Satisfaction}

There are two principal interpretations of satisfaction within literature; satisfaction as a process and satisfaction as an outcome (Cooper et al. [3]). Early concepts of satisfaction research have typically defined satisfaction as a postchoice evaluative judgment concerning specific purchase decisions (Oliver [4], Churchill and Surprenant [5]). Customer satisfaction is the most widely accepted model, in which satisfaction is a function of disconfirmation, which in turn is a function of both expectations and performance (Oliver [4], cited in Lushakuzi [1]).

This model suggests that the effects of expectations are primarily through disconfirmation, but they also have found a direct effect through the perceived performance on satisfaction (Yi [6]). Swan and Combs [7] were among the first to argue that satisfaction is associated with performance that fulfils expectations, while dissatisfaction occurs when performance falls below expectations. In addition, Poisz and Von Grumbkow [8] view satisfaction as a discrepancy between the observed and the desired. This is consistent with the value-percept disparity theory (Westbrook [9]), which was developed in response to the problem that customers could be satisfied by aspects, for which expectations may never exist (Yi [6]) The value-percept theory views satisfaction as an emotional response triggered by a cognitive-evaluative process (Cooper et al. [3]). In other words, it is the comparison of the "object" to one's values rather than an expectation.

Recent literature adds to this perspective in two ways. First, although the traditional model implicitly assumes that customer satisfaction is essentially the result of cognitive processes, new conceptual developments suggest that effective processes may also contribute substantially to the explanation and prediction of customer satisfaction (Fornell [10], Westbrook [9]). Secondly, 
satisfaction is viewed as a judgment, based on the cumulative experience made with a certain product or service, rather than a transaction-specific phenomenon (Wilton and Nicosia [11]).

The general agreement is based on a view that satisfaction is a person's feelings of pleasure or disappointment resulting from comparing a product's perceived performance (or outcome) in relation to a customer's expectations (Kotler [12]). Based on this review, customer satisfaction is defined as the result of cognitive and effective evaluation, where standard is compared to the actually-perceived performance. If the perceived performance is less than expected, the customer would be dissatisfied. On the other hand, if the perceived performance exceeds expectations, the customer would be satisfied. Otherwise, if the perceived expectations are met with performance, customers are in indifferent or neutral. Gustafsson et al. [13] defines customer satisfaction as a customer's overall evaluation of the performance of an offering to date. Parasuraman et al. [14] describes the problem as the "extent of discrepancy between customers' expectation or desires, and their perceptions of the quality of service".

\subsection{The value-percept disparity model}

This model asserts that satisfaction/dissatisfaction is an emotional response triggered by a cognitive-evaluative process in which the perceptions of (or beliefs about) an object, action, or condition are compared to one's values or needs, wants and desires (Locke [15]).

The smaller the disparity between the perception of the object, action or condition and one's values, the more favourable the evaluation and the greater the generation of a positive affect that is associated with goal attainment. Conversely, the greater the value-percept disparity, the less favourable the evaluation, the less the generation of a positive effect and the greater the generation of a negative effect associated with goal frustration, i.e. dissatisfaction (Locke [15]).

This approach requires the following elements

(i) one or more value standards held by the consumer;

(ii) one or more perceptions of the aspects of a product or institution or marketplace behavior; and

(iii) a conscious or subconscious judgment of the relationship between one's perception(s) and one's value(s).

Since it is the attainment of values which consumers seek, rather than the confirmation of their expectations, it is posited that perceptions of products, institutions or marketplace actions are simply tested against the extent to which they meet the consumer's values (Locke [15]). 


\section{Methods}

\subsection{Study design and study area}

This study employed the survey design. The study was conducted in the transit stops and stations of Dar es Salaam to the Arusha National Highway Road. The choice of this road was based on its unique status being the major National Highway Road of the United Republic of Tanzania that is used by the transit with inter-urban passenger buses from southern and eastern regions of the United Republic of Tanzania.

\subsection{Data collection methods}

Multiple methods were used to gather information. Qualitative information generation was guided by a list of questions. Interviews were also conducted and guided by a questionnaire. A non-participation observation technique was employed. Observers stand apart and do not participate in the phenomenon observed (Krishnaswami and Ranganatham [16]). Researchers observe events directly and indirectly. This method was chosen because it was less biased and less erratic in recording accuracy. In this study, a non-probability or non-random sampling (quota sampling) method was adopted to select road passengers for formal interviews.

Table 1: Sample size.

\begin{tabular}{|c|c|c|c|}
\hline $\begin{array}{l}\text { Transit } \\
\text { stops and } \\
\text { stations }\end{array}$ & Respondent & Number & Percentage \\
\hline \multirow{5}{*}{$\begin{array}{l}\text { Dar-Arusha } \\
\text { National } \\
\text { Highway } \\
\text { Road Transit } \\
\text { stops and } \\
\text { stations }\end{array}$} & Passengers at Kibaha & 10 & 21.3 \\
\hline & Passengers at Korogwe & 10 & 21.3 \\
\hline & Passengers at Same & 10 & 21.3 \\
\hline & Passengers at Moshi & 10 & 21.3 \\
\hline & Passengers at Hai & 7 & 14.8 \\
\hline Total & & 47 & 100 \\
\hline
\end{tabular}

Source: Author's Pilot survey - 2012.

\subsection{Data analysis}

The item analysis approach was applied by using the 5 points Likert scale, which was expressed either as a favourable or unfavourable attitude towards the given object, to which the respondents were asked to react. Qualitative data was converted into Likert scales by developing a justifiable ratio scheme. 
The second stage of the analysis of the quantitative data involved the multiple correlation analysis approach.

$$
R_{x y z}=\sqrt{\frac{r_{x y}^{2}+r_{x z}^{2}-2 r_{x y} r_{x z} r_{y z}}{1-r_{y z}^{2}}}
$$

Multiple correlations (R) showed the combined effects of two or more independent variables on the dependent variable (Krishnaswami and Ranganatham [16]). Therefore, the study hypothesis was tested by determining significance levels.

\section{Findings}

\subsection{Booking office service providers vis-a-vis perceived performance and expectations of transit stop service users}

Question one asked the respondents to state whether the booking office service providers are able to perform the promised services very carefully or without errors. The respondents marked one of the options that best reflects his/her opinion. Their responses are illustrated in Table 2.

Table 2: Frequency distribution of the respondents on booking office services.

\begin{tabular}{lc|cccccc}
\hline \multirow{2}{*}{$\begin{array}{l}\text { Transit stop Service } \\
\text { Providers }\end{array}$} & \multicolumn{5}{|c}{ Responses } \\
\cline { 2 - 7 } & $\begin{array}{c}\text { Strongly } \\
\text { agree }\end{array}$ & Agree & Uncertain & Disagree & $\begin{array}{c}\text { Strongly } \\
\text { disagree }\end{array}$ & Total \\
\hline \multirow{2}{*}{$\begin{array}{l}\text { Booking } \\
\text { office }\end{array}$} & Count & - & 20 & 2 & 20 & 5 & 47 \\
\cline { 2 - 7 } & $\%$ & - & 42.5 & 4.3 & 42.6 & 10.6 & 100.0 \\
\hline
\end{tabular}

Source: Field data-2012.

Table 2 indicates that $20(42.5 \%)$ of the respondents agreed that the booking office service providers were able to perform the promised services; this result revealed that the service provided was considered to be satisfactory. Again, the result from Table 2 shows that $20(42.6 \%)$ of the respondents disagreed that the booking office service providers were able to perform the promised services. These results reveal that the service provided was considered to be unsatisfactory. Table 2 indicates further that $5(10.6 \%)$ of the respondents strongly disagreed that the booking office service providers are able to perform the promised services accurately. These results reveal that the services provided 
were considered to be very unsatisfactory. However, $2(4.3 \%)$ of the respondents were uncertain that the booking office service providers were able to perform the promised services, this result indicates that the quality of services provided by transit stops and stations service providers was considered to be neither satisfactory nor unsatisfactory.

Table 3: Total score values (TSV).

\begin{tabular}{l|ccccc}
\hline \multirow{2}{*}{$\begin{array}{l}\text { Booking } \\
\text { Office }\end{array}$} & \multicolumn{3}{|l}{ Responses } & & \\
& SA & Ag & Unc & DS & SD \\
& & & & & \\
\hline Booking & - & 20 & 2 & 20 & 5 \\
$\begin{array}{l}\text { Office } \\
\text { service }\end{array}$ & & $(80)$ & $(6)$ & $(40)$ & $(5)$ \\
\hline
\end{tabular}

Table 3 shows that TSV was between 5 and 80, which is below 150. This result shows that the opinion is unfavourable. For that matter, passengers are not satisfied with the booking office services.

\subsection{Waiting room service providers vis-a-vis perceived performance and expectations of transit stop service users}

Question two asked the respondents to state whether the waiting room service providers are able to perform the promised services very carefully or without errors. The respondents marked one of the options that best reflects his/her opinion. Their responses are illustrated in Table 4.

Table 4: Frequency distribution of the respondents by transit stops and stations on waiting room services.

\begin{tabular}{lc|cccccc}
\hline & \multicolumn{7}{|c}{ Responses } \\
\multirow{nnyyyyyn}{*}{$\begin{array}{l}\text { Transit stop Service } \\
\text { Providers }\end{array}$} & $\begin{array}{c}\text { Strongly } \\
\text { agree }\end{array}$ & Agree & Uncertain & Disagree & $\begin{array}{c}\text { Strongly } \\
\text { disagree }\end{array}$ & Total \\
\hline $\begin{array}{l}\text { Waiting } \\
\text { room }\end{array}$ & Count & 1 & 10 & 7 & 20 & 9 & 50 \\
\cline { 2 - 7 } & $\%$ & 2.2 & 21.7 & 15.2 & 41.3 & 19.6 & 100.0 \\
\hline
\end{tabular}

Source: Field data-2012.

Table 4 indicates that $20(41.3 \%)$ of the respondents disagreed that the waiting room service providers are able to perform the promised services very carefully. These results reveal that the service provided was considered to be unsatisfactory. $10(21.7 \%)$ of the respondents agreed that the waiting room service providers are able to perform the promised services very carefully or without errors. These results reveal that the service provided was considered to be satisfactory. Again, Table 4 indicates that $9(19.6 \%)$ of the respondents 
strongly disagreed that the waiting room service providers are able to perform the promised services very carefully. These results reveal that the services provided were considered to be very unsatisfactory. Other results indicate that 1 $(2.2 \%)$ of the respondents strongly agreed that the waiting room service providers were able to perform the promised service dependably and accurately. These results reveal that the service provided was considered to be very satisfactory. However, 7 (15.2\%) of the respondents were uncertain that the waiting room service providers were able to perform the promised services; this result indicates that the quality of services provided by transit stops and stations service providers is considered to be neither satisfactory nor unsatisfactory. Generally, the results indicate that the majority of the passengers are not satisfied with the waiting rooms services.

Table 5: Total score values (TSV).

\begin{tabular}{|c|c|c|c|c|c|}
\hline \multirow{2}{*}{$\begin{array}{l}\text { Waiting } \\
\text { room }\end{array}$} & \multicolumn{5}{|c|}{ Responses } \\
\hline & SA & $\mathrm{Ag}$ & Unc & DS & $\mathrm{SD}$ \\
\hline $\begin{array}{l}\text { Waiting } \\
\text { room } \\
\text { service }\end{array}$ & $\begin{array}{l}1 \\
(5)\end{array}$ & $\begin{array}{l}10 \\
(40)\end{array}$ & $\begin{array}{l}7 \\
(21)\end{array}$ & $\begin{array}{l}20 \\
(40)\end{array}$ & $\begin{array}{l}9 \\
(9)\end{array}$ \\
\hline
\end{tabular}

Source: Field data-2012.

Table 5 shows that TSV was between 5 and 40, which are below 150. This result shows that the opinion is unfavourable. For that matter passengers are not satisfied with waiting room services.

\subsection{Canteen services providers vis-a-vis perceived performance and expectations of transit stop service users}

Question three asked the respondents to say whether the canteen services providers are able to perform the promised services. The respondents marked one of the options that best reflects his/her opinion. Their responses are illustrated in Table 6 .

Table 6: Frequency distribution of the respondents by transit stops and stations and stations on canteen services.

\begin{tabular}{|c|c|c|c|c|c|c|c|}
\hline \multirow{2}{*}{\multicolumn{2}{|c|}{$\begin{array}{l}\text { Transit stop } \\
\text { Service } \\
\text { Providers }\end{array}$}} & \multicolumn{5}{|c|}{ Responses } & \multirow[b]{2}{*}{ Total } \\
\hline & & $\begin{array}{l}\text { Strongly } \\
\text { agree }\end{array}$ & Agree & Uncertain & Disagree & $\begin{array}{l}\text { Strongly } \\
\text { disagree }\end{array}$ & \\
\hline \multirow{2}{*}{ canteen } & Count & 1 & 34 & 3 & 8 & 1 & 47 \\
\hline & $\%$ & 2.1 & 72.4 & 6.4 & 17.0 & 2.1 & 100.0 \\
\hline
\end{tabular}

Source: Field data-2012. 
Table 6 indicates that $34(72.4 \%)$ of the respondents from transit stops and stations agreed that the canteen service providers are able to perform the promised services very carefully or without errors. These results reveal that the service provided was considered to be satisfactory. $8(17.0 \%)$ of the respondents disagreed that the canteen service providers are able to perform the promised services very carefully or without errors. These results reveal that the service provided was considered to be unsatisfactory. Table 6 further indicates that $1(2.1 \%)$ of the respondents strongly disagreed that the canteen service providers are able to perform the promised services dependably and accurately. These results reveal that the services provided were considered to be very unsatisfactory. $3(6.4 \%)$ of the respondents were uncertain that the booking office service providers are able to perform the promised services very carefully or without errors; this result indicates that the quality of services provided by bus terminal service providers was considered to be neither satisfactory nor unsatisfactory. However, $1(2.1 \%)$ of the respondents strongly agreed that the toilets and canteen service providers are able to perform the promised services very carefully or without errors. These results reveal that the service provided was considered to be very satisfactory.

Table 7: Total score values (TSV).

\begin{tabular}{l|ccccc}
\hline \multirow{2}{*}{$\begin{array}{l}\text { Waiting } \\
\text { room }\end{array}$} & \multicolumn{3}{|l}{ Responses } \\
& SA & Ag & Unc & DS & SD \\
\cline { 2 - 6 } & & & & & \\
\hline $\begin{array}{l}\text { Waiting } \\
\text { room } \\
\text { service }\end{array}$ & 1 & 34 & 3 & 8 & 1 \\
\hline
\end{tabular}

Source: Field data-2012.

Table 7 shows that TSV was between 1 and 136, which are below 150. This result shows that the opinion is unfavourable. For that matter, passengers are not satisfied with waiting room services.

Table 8: Pearson's correlation coefficient between reliability attributes and passenger's satisfaction at Transit stops and stations.

\begin{tabular}{c|lccc}
\hline $\mathrm{S} / \mathrm{N}$ & \multicolumn{2}{|c}{ Attributes } & Corr. Coeff. & Coeff. of Determination \\
\hline 1 & $\begin{array}{l}\text { Waiting } \\
\text { services }\end{array}$ & room & .035 & $.12 \%$ \\
\hline 2 & $\begin{array}{l}\text { Booking } \\
\text { services }\end{array}$ & office & -.170 & $2.89 \%$ \\
\hline 3 & Canteen services & -.428 & $18.32 \%$ \\
\hline
\end{tabular}

Source: Field data-2012. 
The responses for the first and second items indicate a low degree of correlation between reliability attributes and passengers' satisfaction at bus stops and stations. Moreover, there is a moderate correlation between the last equations and this was expected. This implies that passengers who will be fairly satisfied in one of these services will tend to be reasonably satisfied in other services. Again, the coefficient of determination $\left(\mathrm{r}^{2}\right)$ of these variables ranges from $0.12 \%$ to $18.32 \%$ and implies that the variation in satisfaction values is explained by those attributes. Therefore, an increase in performance of the promised services leads to the increase in passenger satisfaction at the transit stops and stations. This result implies that as the performance of the promised services increases so the passengers' satisfaction also increases.

\section{Discussion of study findings}

According to URT [2], the owners of a passenger vehicle can sell their tickets and allow bookings to be made at his or her agents' designated office; this is because a passenger may, at any time before departure, decide to cancel his/her booking. Where a passenger cancels a booking twenty four hours or more before the time of departure, the owner of the licensed motor vehicle shall be obliged to refund the paid fare, if any, to that person immediately after cancellation. It was observed that touts dominate some booking offices at the transit stops and stations, posing as service providers by buying tickets from bus agents at one price and selling them at a higher price. In that case, owners of passenger vehicles or agents do not sell tickets, instead they allow bookings to be made by touts.

It was observed that there were no satisfactory services offered at the transit stops and stations regarding waiting room services. There are simple shaded structures which are very small without a cement floor. For that matter, travellers in most of the transit stops and stations sit on the floor with pieces of luggage and bicycles and other similar things. It was further observed that there are no essential things such as ticket sales and luggage handling facilities. Another shortfall noted was to do with prayer rooms, which passengers can use to speak to God, especially to give thanks or ask for help and there are also no rooms for nursing mothers.

Several short falls were observed including transit stops and stations that are not being fenced; in this sense there is the free movement of different terminal users who deal with unauthorised businesses and as a result, the security of travellers in the transit stops and stations becomes compromised. It was observed further that, at the transit stops and stations there is no security equipment such as closed circuit television for monitoring the movement of buses and transit stops and stations users and also a lack of adequate illumination, especially at night, which makes the security situation more precarious.

There were no Public Address Systems installed at the transit stop and station waiting rooms. In that sense arrival/ departures and some relevant information on things like delays are not announced. Service providers are unable to provide 
correct arrival and departure times for buses, as in the main, they depend on time estimations.

It was perceived that most of the transit stops and stations have no toilet services; if they have then they are not clean enough. The toilet premises have no waste paper baskets or open refuse baskets kept at convenient points. It was further observed that toilets lack baby changing facilities and there are no toilets for disabled persons. This situation forces mothers and disabled people to use alternative places within the transit stops and stations. This situation again causes travellers to throw waste papers everywhere and as a result, the environment around the transit stops and stations become polluted and less user-friendly.

\section{Conclusions}

Satisfaction refers to achieving the things we want. If satisfaction is interpreted as "not going wrong" the transit stops and stations service providers, the transport service regulators and the policy makers should address the complaints of the members of the public. In order to satisfy customers (passengers), the transit stops and stations (service providers) should improve their services. In order to improve passenger's satisfaction at the transit stops and stations in the National highways Dar es Salaam to Arusha in particular, a change towards a positive direction is inevitable. These changes would bring innovative mobility strategies and meet passenger's satisfaction, which would subsequently improve the quality of living of the urban and rural residents through improved mobility options. This needed change would provide a shift from the present unorganised, uncoordinated and unsatisfactory public transport system to a more organised, coordinated and satisfactory transportation system. In this respect, therefore, there is a need to have modern transit stops and stations that would fulfil the current and future needs of travellers within urban and rural areas.

\section{References}

[1] Lushakuzi, S.S., (2011). Analysis of quality service factors and passengers' satisfaction at bus terminals in Dar es Salaam and Morogoro regions - Tanzania, unpublished Doctoral of Philosophy thesis, Mzumbe University (Tanzania).

[2] The United Republic Tanzania (2003). National Transport Policy, Dar es Salaam.

[3] Cooper, R. N., Cooper, B. M., Duhan, F. D. (1989). "Measurement Instrument development Using two Competing Concepts of Consumer Satisfaction", Journal of Consumer Satisfaction and Complaining Behaviour, vol. 2, 22-35.

[4] Oliver, R. L. (1980). "A cognitive Model of the Antecedents and Consequences of Satisfaction Decisions" Journal of Marketing Research, 17, 460-469. C. M. and Page, S. J. (Eds). 
[5] Churchill, G. A., Surprenant, C. (1982). "An Investigation into the Determinants of Customer Satisfaction", Journal of Marketing Research, vol. 19, .491-504.

[6] Yi, Y. (1990). "A Critical Review of Consumer Satisfaction" in Review of Marketing Ed. Valarie A. Zeithaml Chicago: American Marketing Association, 68-123.

[7] Swan, J. E., Combs, L.J. (1976). "Product performance and consumer satisfaction; a new product concept" Journal of Marketing, Vol. 40, April, pp. 25-33.

[8] Poisz, T. B. C., Von Grumbkow, J. (1988). Economic wellbeing, job satisfaction, income evaluation and consumer satisfaction: an integrative attempt. Handbook of economic psychology, Netherlands Kluwer Academic Publishers.

[9] Westbrook, R. A. (1983). "Intrapersonal Affective Influences on Consumer Satisfaction with Products" Journal of Consumer Research 7 (June): 49-54.

[10] Fornell, C. (1992). "A National Customer Satisfaction Barometer: The Swedish Experience”, Journal of Marketing, 55 (January). 1-22.

[11] Wilton, P. C., Nicosia, Satisfaction, European research, 14, 4-11, F. M. (1986). Emerging paradigms for the study of consumers.

[12] Kotler, P. (2003). Marketing Management Fifth edition, New Jersey, Pearson Education Inc.

[13] Gustafsson, A., Jonhson, M. D., Roos, I. (2005). 'The Effects of Customer Satisfaction, Relationship Commitment Dimension, and Triggers on Customer Relation' American Marketing Association, ISSN: 0022-2429.

[14] Parasuraman, A., Zeithaml, V, A., Berry, L. B. (1990). Delivering Quality Service, New York, Free Press.

[15] Locke, Edwin A. (1969), "What is Job Satisfaction?" Organizational Behavior and Human Performance, 4, 309-336.

[16] Krishnaswami, O., Ranganatham R. (2007). Methodology of Research in Social Sciences, Mumbai, Himalaya Publishing House. 